\title{
EREBEA
}

Revista de Humanidades y Ciencias Sociales

Núm. 10 (2020), pp. 69-84

ISSN: 0214-0691

http://dx.doi.org/10.33776/erebea.v10i0.4955

\section{Dream Teens Project in the Promotion of Social Participation and Positive Youth Development of Portuguese Youth}

\author{
Cátia Branquinho \\ Aventura Social/ Faculty of Human Kinetics, University of Lisbon, Portugal \\ $I S A M B$, Medicine Faculty, University of Lisbon, Portugal
}

Diego Gomez-Baya Department of Social, Developmental and Educational Psychology, Universidade de Huelva, Espanha

Margarida Gaspar de Matos Aventura Sociall Faculty of Human Kinetics, University of Lisbon, Portugal ISAMB, Medicine Faculty, University of Lisbon, Portugal

ABSTRACT

Aim: To present a youth participatory action-research program developed in Portugal - Dream Teens project, focused on promoting social participation and active citizenship, alongside with its impacts. Methodology: In total, Dream Teens brought together 147 participants ( girls $=66.66 \%$; boys=33.33\%). Five studies were conducted to assess its impact: (i) pre and post test assessment of actionresearch skills among participants (feelings and action-oriented competencies, interpesonal skills, problem solving skills, humanitarianism and feelings towards life); (ii) analysis of the most and least prioritized themes of the program. (iii) interpretation of the project's results by core group of
Resumen

Objetivo: Presentar un programa de investigación-acción participativa para jóvenes desarrollado en Portugal (Proyecto Dream Teens), centrado en promover la participación social y la ciudadanía activa, junto con sus consecuencias. Metodología: En total, el proyecto Dream Teens reunió a 147 participantes $($ niñas $=66,66 \%$; niños $=$ $33,33 \%)$. Se realizaron cinco estudios para evaluar su impacto: (i) evaluación previa y final de las habilidades de investigaciónacción entre los participantes (sentimientos y competencias orientadas a la acción, habilidades interpersonales, habilidades para la resolución de problemas, humanitarismo y sentimientos hacia la vida); (ii) análisis de los temas más y menos priorizados del programa, 
participants (iv) interpretation of the project's results by stakeholders; (v) actionresearch projects implemented by core group within their community. A multimethod and multiparticipant approach was used. Results: Although in the pre and post-test there are no statistically significant differences in any action-research skill, there is a perception of overall improvement by young people. The most prioritized themes are associated to the cognitive and relational levels (in what society and friends are concerned, respectively); and the least prioritized is the cognitive level but only for school-related topics. When interpreting the results, participants report positive impacts on personal development, actions, feelings of social support and relationships. In turn, stakeholders clarify that the absence of statistically significant impacts is common in programs that aim to promote competencies, that school is not the main concern of this generation, and that bureaucracies in accessing institutions are due to their difficulty in self-reforming. Two main projects and a conference emerged from the core group's work. Conclusions: results suggest that participatory research programs with young people can constitute important resources to promote the positive development of this population.

\section{KeYwords}

Positive youth development; Social participation; Participatory research programs with young people; Dream Teens Project; Impacts.

Fecha de recepción: 24 de septiembre de 2020 Fecha de aceptación: 26 de octubre de 2020 (iii) interpretación de los resultados del proyecto por parte del grupo principal de participantes (iv) interpretación de los resultados del proyecto por parte de las partes interesadas; (v) proyectos de investigaciónacción implementados por grupos centrales dentro de su comunidad. Se utilizó un enfoque multimétodo y multiparticipante. Resultados: Aunque en la prueba previa y posterior no se hallaron diferencias estadísticamente significativas en ninguna habilidad de investigación-acción, hay una percepción de mejora general por parte de los jóvenes. Los temas más priorizados están asociados con los niveles cognitivo y relacional (en lo que a sociedad y amigos se refiere, respectivamente); y el menos priorizado es el nivel cognitivo, pero sólo para temas relacionados con la escuela. Al interpretar los resultados, los participantes informaron de impacto positivo en el desarrollo personal, acciones, sentimientos de apoyo social y relaciones. A su vez, los organizadores indicaron que la ausencia de impactos estadísticamente significativos es común en los programas que buscan promover competencias, que la escuela no es la principal preocupación de esta generación de jóvenes y que las burocracias en el acceso a las instituciones se deben a su dificultad para auto-reformarse. Del grupo principal de participantes surgieron dos proyectos principales y una conferencia. Conclusiones: los resultados sugieren que los programas de investigación participativa con jóvenes pueden aportar recursos importantes para promover el desarrollo positivo de esta población.

\section{Palabras Clave}

Desarrollo juvenil positivo; Participación social; Programas de investigación participativa con jóvenes; Proyecto Dream Teens; Impactos. 
Dream Teens Project in the Promotion of Social Participation and Positive Youth Development of Portuguese Youth

Focus of many studies, the concept Positive Youth Development (PYD) may be associated with (i) a description of the development process; (ii) categorization of programs and organizations that promote activities for the development of this generation; or (iii) doctrine directed to results based on the strengths of young (Whitlock \& Hamilton, 2001). In this conception, the young person is seen as a resource capable of being developed (Damon, 2004; Roth \& Brooks-Gunn, 2003), an important agent of change.

Lerner and colleagues $(2011 ; 2013)$, based on their Theory of Development Systems, present a categorization of " 5 C's", believe that the Competence in the emotional, academic, social and vocational areas; the Confidence in identity; the Character related to values, integrity and morals; the Connection with oneself and with others; and the Care associated with empathy and compassion, can not only promote a more PYD, but also bring important benefits to the context in which youth are inserted (family, community and society).

In a recent systematic review of the literature, Catalano and colleagues (2019) highlight the skills that the PYD promotes, along with the physical and mental health improvement, better education and employment, and safer, inclusive and equal communities. In this scenario of mutually beneficial relationships, a healthier and more positive life path is facilitated throughout life (Benson, Scales, Hamilton, \& Sesma Jr., 2006) - the young person's prosperity (Lerner, Dowling, \& Andersen, 2003), as well as the "6C: Contribution", associated with involvement and participation (Lerner, 2004).

Based on the argument that this group has the capacity to contribute with an important knowledge of their problems and needs (Ozer \& Piatt, 2017), centered on their own Voice and experience (Cammarota \& Fine, 2008; Livingstone, Celemencki, \& Calixte, 2014; Kim, 2016), youth participatory action-research programs have assumed greater prominence in recent decades. Fundamentally developed in the United States, they are still uncommon practices in Europe.

Rodriguez and Brown (2009), in a conceptualization of these programs, present three principles: (i) they are focused on the experiences and concerns of young people; (ii) its methodological and pedagogical process includes the collaboration and participation of young people; (iii) have a transformative 
characteristic that facilitates the change of theories and practices that improve the lives of young people and their community.

With broad and positive impacts, at the academic, professional, social, interpersonal, cognitive, agency and leadership levels (Anyon, Bender, Kennedy, $\&$ DeChants, 2018), youth participatory action-research programs allow for an adult-young mentoring relationship, the sharing of power during the process, the acquisition and development of skills, consultancy, enhancing the practice and the debate centered on social change (Ozer \& Douglas, 2015).

In this work, a youth participatory action-research program developed in Portugal will be presented, as well as its impacts.

\section{Method}

\section{PROCEDURE AND PARTICIPANTS}

In a first phase, in order to establish partnerships that would allow reaching the maximum number of young people, several professionals from institutions linked to this population were contacted. This was followed by a national campaign to attract applications, which took place in March 2014 and April/ May of the same year. This campaign was supported by a television channel and public figures in the field of television, humor, sports and music. In total, 298 applications were received via Google Forms platform. After checking the inclusion criteria: age between 11 and 18 years; permission of parent or guardian; letter of motivation and expectations regarding the project; and exclusion of repeated applications, 147 applications (girls=66.66\%; boys $=33.33 \%$ ) have been considered.

All candidates were interviewed via Skype, being young people who showed greater motivation, critical and leadership spirit in the letters submitted and interview, integrated in the experimental group and the others in the control group. The experimental group included 67 participants and the control group 80. It should be noted that the young people in the experimental group were integrated into one of the six thematic working groups (according to their preference): Theme 1 - Personal resources and well-being; Theme 2 - Social support; Theme 3 - Love and sexuality; Theme 4 - Consumption and dependencies; Theme 5 - Recreation, physical activity and leisure; Theme 6 - Citizenship and social participation.

Both groups were organized in closed groups - control and experimental on the social network Facebook, through challenges (centered on the themes presented above) published biweekly by project researchers. These groups were supervised by specialist researchers in specific areas of work.

For a year, young people discussed the main needs and strategies for their problems, carried out group research projects, and developed a letter with 30 recommendations in the areas of health and well-being. These recommendations 
were based on a research carried out by the researchers, of conceptual frameworks, intervention programs and politically framed national and international documents.

The 1st National Dream Teens Meeting marked the end of this first year. 48 young people were present at this event, in which they had the opportunity to present their research work and deliver the letter of recommendations to the Secretary of State for Health. In order to study the impact of the project, a pretest questionnaire was applied at this stage of the study.

In a new phase and in a test of young people's motivation and involvement, the experimental and control groups were merged $(n=91)$. These young people have the opportunity to invite their most active friends to join the network $(\mathrm{n}=30)$. In addition, work meetings were held in two districts (Lisbon ( $\mathrm{n}$ = 24) and OPorto $(\mathrm{n}=17)$ ) with a higher prevalence of participants. On this day, and to get support from their schools and municipalities in the development of their projects, the young people were prepared to present the project Dream Teens and health status of portuguese youth - results of the study Health Behavior in School-aged Children 2010/ World Health organization - HBSC/ WHO (http://www.hbsc.org/, coordinated by the head of the network).

During this year, the challenges launched on Facebook in the previous phase were studied, the book "Adolescents: safe navigation through unknown waters. Coisas de Ler (Matos, 2015)" was developed, which featured the voice of young Dream Teens, as well as a Youtube channel, Twitter, a Blog and a television channel. All channels have been streamlined by Dream Teens, under the supervision of researchers.

After another year and marking the end of another phase, the 2nd National Dream Teens Meeting was held $(\mathrm{n}=49)$. In this event, presentations of individual research work were carried out, under the eyes of their friends, researchers from the international network HBSC/ WHO and the Minister of Health. The posttest impact assessment instrument was applied.

Authentic junior research specialists, a core group $(n=15)$ of more active young people took over the leadership of the network. For another year, this group activated the other young people in the network and developed projects in their life contexts.

In order to involve young people in all phases of the research process and in project analysis, focus groups and individual interviews with members of this group were developed. At the same time, they participated in scientific publications and scientific congresses.

To motivate stakeholders for youth social participation, individual interviews were conducted.

The Dream Teens project was approved by the Ethics Committee of the Academic Medicine Center of Lisbon. 


\section{INSTRUMENTS}

In studying the impact of the project, a multi-method and multiparticipant approach was used.

\section{PRE AND POST-TEST IN IMPACT ASSESSMENT}

Developed in order to study the initial and final impact of the project (Branquinho \& Matos, 2018), it allowed studying five dimensions: (i) feelings and competencies for action; (ii) interpersonal skills; (iii) competencies for problem resolution; (iv) humanitarianism; (v) feelings towards life. The questions were composed by a 5 points Likert scale $(1=$ strongly disagree to $5=$ strongly agree), as well as a range of their perception of change after joining the project (got worse, nothing has changed, improved). In parallel, open questions were applied to study involvement in leadership and volunteering activities, as well as expectations for the future.

\section{CHALLENGES IN THE COLLECTION OF MATTERS THAT ARE MORE} AND LESS PRIORITIZED

Based on the discussion challenges posted on Facebook groups (Branquinho, Cruz, \& Matos, 2017), drivers of the collection of their needs and strategies for their problems, a summary table of the challenges launched in each theme was created (with categories and subcategories), number of challenges, respective responses and average responses per challenge.

\section{INTERVIEW GUIDES}

Two interview scripts were created. A structured one, applied to the core group in the form of a focus group and individual interview, in which young people were invited to identify the project's Strengths, Weaknesses, Opportunities and Threats (Fine, 2009), as well as its impact on their development as individual, in his individual action, social support, family, school and community (Branquinho, Cerqueira, Ramiro, \& Matos, 2018); and another, semi-structured, applied to stakeholders in the areas of health, education and migration in an individual interview format (Branquinho, Cunha, Grothaussen, \& Matos, 2019). In it, the following study results were explored: (i) weak prioritization of school-related issues; (ii) bureaucracies found in access to political power bodies; (iii) absence of statistically significant differences in the pre and post-impact tests; and (iv) the perception of young people's participation and their inclusion in the policies that affect them.

\section{RECORD OF BEHAVIORS AND CRITICAL INCIDENTS}

In the analyses of the work carried out by the core group, critical behaviors and incidents were recorded. 


\section{DATA ANALYSIS}

Different methods were used in the data analysis.

\section{Quantitative Analysis of Data Using the SPSS SofTWARE}

In the study of project impacts (Branquinho \& Matos, 2018), an exploratory factor analysis was performed for all the items of the original instrument; and Cronbach's alpha for all items of the five dimensions found, along with a descriptive analysis. In the study of the percentages, a comparative analysis of the pre and post-test was followed through the Student $t$ test for paired samples and a study of the perceptions of the impact (got worse, nothing change, improved). Based on the small number of respondents, the level of significance was set at 0.001 .

\section{Qualitative Data Analysis Using NVIVo SofTWare}

The data collected through the challenges posted on Facebook (Branquinho, Cruz, \& Matos, 2017) were initially subject to a content analysis, based on an interpretative approach and later grouped according to the Integrative Conceptual Model for Healthy Development of Adolescents (Kia-Keating et al., 2011). The summary table allowed an analysis of the most and least prioritized themes. In the qualitative analysis software NVivo v. 11, trees of nodes and sub-nodes of the youth comments were created, with experimental group and control attributes, age, sex and access the exemplary excerpts.

Interviews to core group followed the same initial content analysis methodology (Branquinho et al., 2018), continued by the search for a system that would allow sustain the results. From this research, the SWOT Analysis (Fine, 2009) and the COM-B model (Michie, van Stralen, \& West, 2011) emerged. A new content analysis was performed, followed by the association and content coding.

In NVIVO v.11 the response matrix allowed to view the number of responses in each node and sub-node and to know the 30 terms most often spoken through word clouds (number of characters equal to or greater than eight in order to ignore prepositions and conjunctions and grouped by synonyms) in each node - Strengths, Weaknesses, Opportunities and Threats. This was followed by a study based on word clouds per node and sub-node - individual development, individual action development, social support, family, school and community (three most frequent words, number of characters equal to or greater than eight and aggregated synonyms) in order to fit the most frequent words in their context. A conceptual map facilitated the presentation of results.

Also using a qualitative methodology, a study was carried out on the content of individual interviews conducted with stakeholders linked to working with young people (Branquinho et al., 2019). Targeted by an initial content analysis, highlighting the most relevant material, nodes and cases (attributes: name, gender 
and link to the project) were created in NVIVO v. 12. An array of responses facilitated the display of responses by node, and the word clouds the terms most frequently spoken (four most frequent words with a number equal to or greater than eight characters and grouped by synonyms). These terms facilitated the identification of the exemplary passages.

The analysis of clusters by words similarity showed that the analysis of the comments should be carried out as a whole.

\section{QUALITATIVE ANALYSIS BASED ON OBSERVATION AND RECORDS}

In the study of the core-group work, the descriptive log behaviors allowed the creation of reflective records.

\section{Results}

In the first impact assessment study, in a pre- and post-test analysis (Branquinho \& Matos, 2018), although no statistically significant differences were identified in the dimensions studied: feelings and competencies for action, interpersonal skills, competencies for problema resolution, humanitarianism and feelings towards life, a perception of improvement was evident. There was also an increase in their involvement in volunteering activities and an improvement in their future expectations, with the vast majority mentioning that they intend to continue their studies at a university and that 10 years from now he will be working in his area of interest.

\begin{tabular}{l|c|c|c|c|c} 
Factors & Items & $\mathrm{N}$ & $\mathrm{M}$ & SD & Cronbach \\
\hline Feelings and competencies for action & 9 & 43 & 31.14 & 7.415 & .905 \\
\hline Interpersonal skills & 6 & 44 & 19.64 & 3.804 & .745 \\
\hline Competencies for problem resolution & 4 & 46 & 12.3 & 3.140 & .817 \\
\hline Humanitarianism & 3 & 46 & 13.39 & 2.081 & .826 \\
\hline Feelings towards life & 3 & 46 & 11.37 & 2.398 & .639
\end{tabular}

Internal consistency of the scales $(N=46)$. Originally published in Branquinho \& Matos (2018).

Note: $M=$ Mean; $S D=$ standard deviation

With a strong interest in issues associated with critical thinking related to society (cognitive level) and friends (relational level), young people had a lower participation in school-related topics (cognitive level) (Branquinho, Cruz, \& Matos, 2017).

In their individual interviews and focus group (Branquinho et al., 2018), they highlighted the existence of objectives in the project, acquired knowledge and face-to-face meetings as forces; as weaknesses the difficulty in dealing with 
empowerment and the weak participation of some elements; the collaboration of some teachers and some local authorities to receive young people; and the bureaucracy to develop a project, the lack of support from the community and some politicians and teachers as threats to participation.

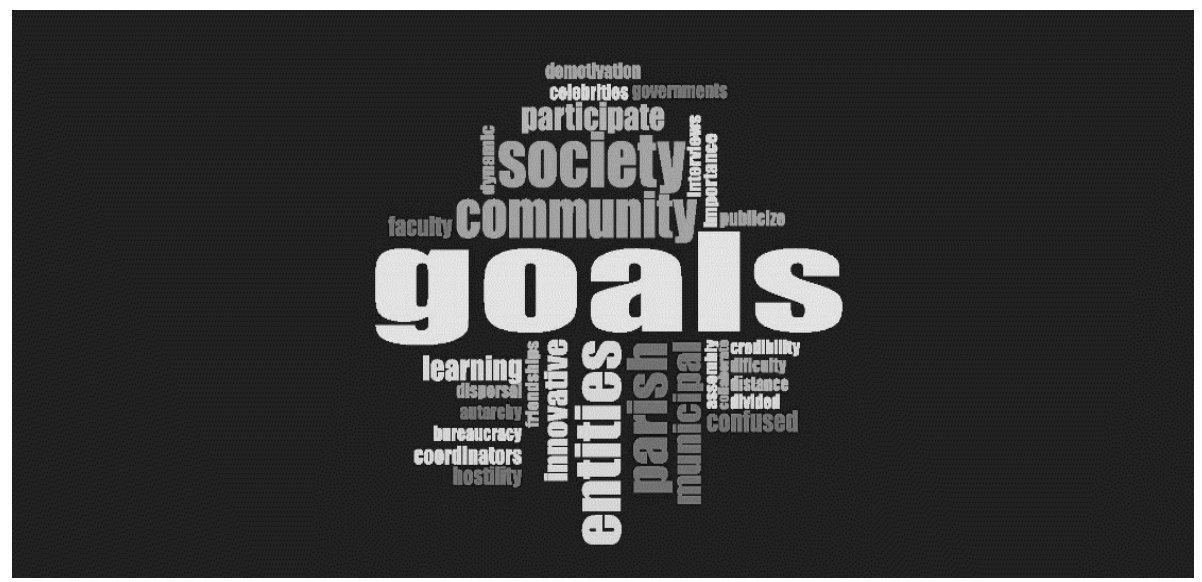

Figure 1. Challenges categorization. Originally published in Branquinho et al. (2018). Image 1. Word cloud of the individual interviews

The young people highlighted that their participation in the program promoted their skills in terms of their personal development, promoted their self-esteem and personal goals, sense of participation in the community, communication skills and respect for themselves and for others; in their individual actions, with greater political empowerment, greater action-research skills and confidence for action; as well as its opportunities, enhancing the feeling of greater social support, through the establishment of contacts and feeling of support on the part of some organs of political power; better relations with the family, resulting in a more active listening, argumentative power and development of new interests; in the school context, in improving relations with teachers and colleagues, in better academic performance, coping strategies to deal with frustration, better acceptance of oneself and the other; and in the community. Although there have been no significant changes in this, they believe that their work will have repercussions in the future.

In the Voice of the stakeholders (Branquinho et al., 2019), in the absence of statistically significant differences in the study of the impact of the project, it was argued that this is a common result in the skills promotion programs, with an overestimation of the initial moment; that they can evaluate according to social desirability; and that after some time young people stop investing. 


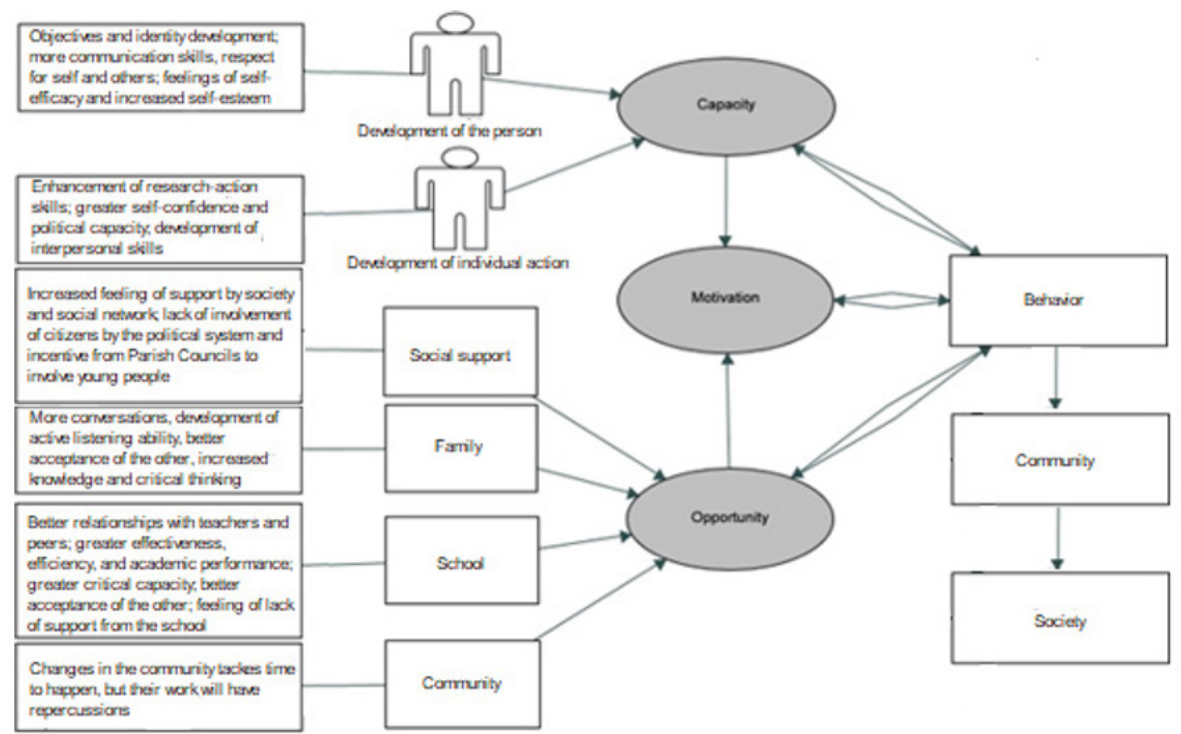

Figure 2. Conceptual map of Dream teens impacts. Originally published in Branquinho et al. (2018).

In the lower prioritization of issues related to the school, they say it may be related to the constant debate that the school is subject to; which may be losing the relevance and transversality of youth concerns, taking the opportunity to censor the excess focus on evaluation moments. They argue that the school has not kept up with developments.

Enhance the bureaucracies that young people face when trying to access the institutions is due to the difficulty that instituions have to self-reform.

They agree that little is invested in youth public policies and reinforce that institutions are not prepared to listen to young people.

Lastly, in the study of the leadership of the core group, in addition to its participation in congresses, support in the development of scientific articles, dynamization of the network's communication channels, the following interventions in their life contexts stand out:

- Dream Yold: Documentary - ACTIVE (MIND): growing old with attitude! ( $\mathrm{n}=100)$, allowing the voice of senior population in the areas of health and well-being.

- Dream Kids focused on the needs, concerns and solutions to the problems of children under the age of $12(\mathrm{n}=12)$, was developed in a leisure activity center, enabling a more active "voice" on topics related to everyday life.

- 1st National Dream Teens Conference: The voice of young people in Azores, which was attended by political representatives from the areas of education and youth, with the presentation of the Dream Teens project and the results of the HBSC/ WHO 2014 study. 


\section{ConClusions AND Discussion}

In the pre and post-test analysis, to assess the impact of the project (Branquinho \& Matos, 2018), although there were no statistically significant differences in the dimensions studied, namely: feelings and competencies for action, interpersonal skills, competencies for problem resolution, humanitarianism and feelings towards life, there was a perception of improvement. A program to promote personal and social skills revealed similar results (Branquinho, Fauvelet, Cruz, Santos, Gaspar, \& Matos, 2017).

Along with the perception of improvement, there was also an increase in their involvement in volunteer activities and improvement of their expectations for the future, hoping to continue their studies in university and 10 years from now they will be working in their area of interest.

In search of the matters most and least prioritized (Branquinho, Cruz, \& Matos, 2017), it highlights the critical thinking related to the society and friends as preferred topics pertaining to cognitive and relational level, respectively, contrasting the slightest interest in issues related to the school, part of the cognitive level. Other studies support these results, showing that young people attribute an important role to friends during their development process (Berndt, 2002), and reveal a certain disenchantment with school (Matos, Gaspar, Cruz, \& Neves, 2013; Matos, Gaspar, Tomé, \& Cruz, 2012).

In the SWOT analysis of the project, as well as the assessment of their impact (Branquinho et al., 2018), are highlighted the existence of objectives, the knowledge gained and face-to-face meetings as forces; the difficulty in dealing with empowerment and the little participation of some young people as weaknesses; the availability of some teachers and political bodies to receive them as opportunities; and the bureaucracies associated with the development of a project, and the lack of support from the community, of some teachers and politicians as threats.

Regarding its impact, results were highlighted in terms of its development as a person, in the increase of its self-esteem and personal goals, communication skills and respect for itself and for others. Ozer (2017) argues that participation in youth participatory action-research programs promotes identity development on its participants. As in other youth participatory action-research program, Dream Teens showed repercussions on self-efficacy feelings (Checkoway \& RichardsSchuster, 2003) and competencies for action (Kulbok et al., 2015; Suleiman, Soleimanpour, \& London, 2006). In the development of individual actions, greater political empowerment and the relationships created were also mentioned, as well as a greater feeling of social support, based on the establishment of contacts and support from some institutions of political power. In the family relationship, positive impacts are also reported, with the promotion of more active listening, the ability to argue and the development of new interests. 
In the context of school are identified improvements in relationships with teachers and peers, better academic performance and coping strategies to deal with frustration. Better acceptance of oneself and the other is also reported. In a recent systematic review, Anyon and colleagues (2018) find a benefit from participating in these programs in terms of promoting academic skills. In the community context, although they do not identify significant changes, they are certain that in the future their work will have repercussions.

In the inclusion of stakeholders in the interpretation of project results (Branquinho et al., 2019), they argue that the absence of statistically significant differences in the pre and post-test is common in programs to promote personal and social skills; that may be in accordance with social desirability or manipulate responses to improve the perspective on themselves (Kaminska \& Foulsham, 2013).

In the weak prioritization of themes related to the school, they emphasize that it is losing the relevance and transversality of the concerns of this generation, even though it constitutes an important promoter of socialization (Garbarino, 1978; Garibaldi \& Josias, 2015). They also argue that too much weight is placed on evaluations and that the school has not kept pace with the times.

Explaining that young people face many bureaucracies when trying to access the world of adults, they say that institutions have difficulty in self-reform and that those who receive them are not prepared for youth participation. Another study justifies that even in institutions where Youth Councils are established, barriers such as bureaucracies are frequently encountered (Blakeslee, 2018).

In their perspective on the participation of young people and their involvement in policies that directly affect them, they agree that little is invested in youth policies. Akiva, Cortina and Smith (2014) stress the importance of involving young people significantly, arguing that an investment in structures and processes that include this population, promote the well-being of individuals and the community.

Finally, in the study of the core group in the leadership of the network, in addition to its participation in scientific conferences and in supporting the development of articles, stands out its work in the development of projects/ initiatives in their life contexts, specifically: Dream Yold: Documentary ACTIVE (MIND): grow old with attitude, Dream Kids and 1st National Dream Teens Conference: The voice of young people in Azores.

\section{IMPLICATIONS FOR PRACTICE AND FUTURE DIRECTIONS}

Considered a good practice in the area of health and well-being by the World Health Organization and Ministry of Education, this project and its methodology have already served as inspiration for the development of other programs: Dreaming with Survivors (https://www.acreditar.org.pt/en/base3_detail/7/60), created to identify the key needs and strategies for the problems of infantile 
cancer survivors, this network promotes their social participation; Dream Kids, developed with students from the 3rd year of a primary school (Branquinho et al., 2018a); expansion to senior - Dream Yold; Improve the Youth, focused on the promotion of mental health of Polish and Portuguese youth; reference methodology in the promotion of personal and social skills within the scope of the Gulbenkian Academies (https://gulbenkian.pt/academias/publication/ dream-teens/).

From the need to test the Dream Teens model in a community, in order to compare its impact with the initial project, the Dream Teens project is underway powered by Cascais Jovem. This study is funded by the Cascais City Council and aims to enhance youth entrepreneurship, social participation and more active citizenship. Also based on a participatory model, but this intergenerational, the project \#GeraçóesComVoz is under development, centered on the study of intergenerational justice.

\section{REFERENCES}

Akiva, T., Cortina, K. S., \& Smith, C. (2014). Involving Youth in Program Decision-Making: How Common and What Might it Do for Youth? Journal of Youth and Adolescence, 43(1), 1844-1860. doi: 10.1007/s10964-014-0183-y

Anyon, Y., Bender, K., Kennedy, H., \& Dechants, J. (2018). A Systematic Review of Youth Participatory Action Research (YPAR) in the United States: Methodologies, Youth Outcomes, and Future Directions. Health Education \& Behavior, 45(6), 865-878. doi: 10.1177/1090198118769357

Benson, P. L., Scales, P. C., Hamilton, \& Sesma, A. (2006). Positive Youth development: Theory, research and application. In W. Damon, R.M., \& Lerner (Eds.), Handbook of Child Psychology (6th ed., pp. 894-941). New York: Wiley.

Berndt, T. J. (2002). Friendship quality and social development. Current Directions in Psychological Science, 11, 7-10. doi:10.1111/1467-8721.00157

Blakeslee, J. (2018). Assessing the Meaningful Inclusion of Youth Voice in Policy and Practice: State of the Science. Portland: Research and Training Center for Pathways to Positive Futures, Portland State University.

Branquinho, C., \& Matos, M. G. (2018). Why "Dream Teens": was there an impact after a two-year participatory action-research program? Child Indicators Research, 11(46), 1-15. doi: 10.1007/s12187-018-9585-9

Branquinho, C., Cerqueira, A., Ramiro, L., \& Matos, M. G. (2018). Youth "have a voice" - qualitative exploration of a participatory action-research program. Acta Psychopathologica, 4(4), 22-33. doi: 10.4172/2469-6676.100177 
Branquinho, C., Cunha, P., Grothaussen, T., \& Matos, M. G. (2019). Stakeholders' voice, about a Youth Participatory Action-research Program: a qualitative study. Psicologia, Saúde \& Doenças, 20(3), 824-837. doi: $10.15309 / 19$ psd200321

Branquinho, C., Fauvelet, C., Cruz, J., Santos, T., Gaspar, T., \& Matos, M. G. (2018a). Dream Kids, dar voz às crianças: O futuro já começou, com autonomia e responsabilidade [Dream Kids, give voice to children: The future already started, with autonomy and responsibility]. Revista de Psicologia da Criança e do Adolescente, 8(2), 13-27.

Branquinho, C., Cruz, J., \& Matos, M. G. (2017). Dream Teens - a "voz" dos jovens na discussão de problemas da sua geração [Dream Teens - the youth "voice" in the discussion of problems of their generation]. Saúde $e$ Desenvolvimento Humano, 5(3), 19-25. doi: 10.18316/sdh.v5i3.3565

Cammarota, J., \& Fine, M. (2008). Revolutionizing education: youth participatory action research in motion. England: Routledge Taylor \& Francis Group.

Catalano, R. F., Skinner, M. L., Alvarado, G., Kapungu, C., Reavley, N., Patton, G. C. ... Petroni, S. (2019). Positive Youth Development Programs in Lowand Middle-Income Countries: A Conceptual Framework and Systematic Review of Efficacy. Journal of Adolescent Health, 65(1), 15-31. doi: 10.1016/j. jadohealth.2019.01.024

Checkoway, B., \& Richards-Schuster, K. (2003). Youth Participation in Community Evaluation Research. American Journal of Evaluation, 21(1), 2133. doi: $10.1177 / 109821400302400103$

Damon, W. (2004). What is positive youth development? The Annals of the American Academy of Political and Social Science, 591(1), 13-24. doi: 10.1177/0002716203260092

Garbarino, J. (1978). The Role of Schools in Socialization to Adulthood. The Educational Forum, 42(2), 169-181. doi: 10.1080/00131727809336299

Garibaldi, M., \& Josias, L. (2015). Designing schools to support socialization processes of students. Procedia Manufacturing, 3, 1587-1594. doi: 10.1016/j. promfg.2015.07.446

Kaminska, O., \& Foulsham, T. (2013). Understanding sources of social desirability bias in different modes: Evidence from eye-tracking. ISER Working Paper Series, No. 2013-04. Colchester: University of Essex, Institute for Social and Economic Research (ISER). Retrieved from https://www.econstor.eu/ bitstream/10419/91698/1/737967706.pdf

Kia-Keating, M., Dowdy, E., Morgan, M. L., \& Noam, G. G. (2011). Protecting and promoting: An integrative conceptual model for healthy development of 
adolescents. The Journal of Adolescent Health, 48(3), 220-228. doi: 10.1016/j. jadohealth.2010.08.006

Kim, J. (2016). Youth involvement in participatory action research (PAR): challenges and barriers. Critical Social Work, 17(1), 38-53.

Kulbok, P. A., Meszaros, P.S., Bond, D. C., Thatcher, E., Park, E., Kimbrell, M., \& SmithGregory, T. (2015). Youth as partners in a community participatory project for substance use prevention. Family \& Community Health, 38(1), 3-11. doi: 10.1097/FCH.0000000000000061

Lerner, R. M. (2004). Liberty: Thriving and civic engagement among America's youth. Thousand Oaks: Sage Publications.

Lerner, R. M., Dowling, E. M., \& Anderson, P. M. (2003). Positive Youth Development: Thriving as the Basis of Personhood and Civil Society. Applied Developmental Science, 7(3), 172-180. doi: 10.1207/S1532480XADS0703_8

Lerner, J. V., Bowers, E. P., Minor, K., Boyd, M. J., Mueller, M. K., Schmid, K. L. ... Lerner, R. M. (2013). Positive youth development: processes, philosophies, and programs. In R. M. Lerner, M. A Easterbrooks, \& J. Mistry (Eds.), Handbook of Psychology (pp. 365-392). New Jersey: Wiley.

Lerner, R. M., Lerner, J. V., Lewin-Bizan, S., Bowers, E. P., Boyd, M., Mueller, M. ... Napolitano, C. (2011). Positive youth development: processes, programs, and problematics. Journal of Youth Development, 6(3), 40-64. doi: 10.5195/ jyd.2011.174

Livingstone, A., Celemencki, J., \& Calixte, M. (2014). Youth participatory action research and school improvement: the missing voices of black youth in montreal. Canadian Journal of Education, 37(1), 283-307.

Matos, M. G. (Coord.). (2015) Adolescents: safe navigation through unknown waters. Lisbon: Coisas de Ler.

Matos, M. G., Gaspar, T., Cruz, J., \& Neves, A. M. (2013). New Highlights About Worries, Coping, and Well-being During Childhood an d Adolescence. Psychology Research, 3(5), 252-260.

Matos, M. G., Gaspar, T., Tomé, G., \& Cruz, J. (2012). Worries and well-being during childhood and adolescence. Pakistan Journal of Clinical Psychology, 11(1), 3-14.

Michie, S., van Stralen, M., \& West, R. (2011). The Behaviour Change Wheel: A new method for characterising and designing behaviour change interventions. Implementation Science, 23, 6-42. doi: 10.1186/1748-5908-6-42

Ozer, E. J. (2017). Youth-led participatory action research: Overview and potential for enhancing adolescent development. Child Development Perspectives, 11, 173-177. doi: 10.1111/cdep.12228 
Ozer, E., \& Douglas, L. (2015). Assessing the key processes of YouthLed Participatory Research: Psychometric analysis and application of an observational rating scale. Youth \& Society, 47(1), 29-50. doi: 10.1177/0044118X12468011

Ozer, E. J., \& Piatt, A. A. (2017). Youth-led Participatory Action Research (YPAR): Principles Applied to the US and Diverse Global Setting. In N. Wallerstein, B. Duran, J. Oetzel, \& M. Minkler, Community-Based Participatory Research for Health (pp. 97). California: Jossey-Bass.

Rodriguez, L. F., \& Brown, T. M. (2009). From voice to agency: Guiding principles for participatory action research with youth. New Directions for Youth Development, (123), 19-34. doi: 10.1177/1090198118769357

Roth, J. L., \& Brooks-Gunn, J. (2003). What exactly is a youth development program? Answers from research and practice. Applied Developmental Science, 7, 94-111.

Suleiman, A. B., Soleimanpour, S., \& London, J. (2006). Youth Action for Health Through Youth-Led Research. Journal of Community Practice, 14(1-2), 125-145. doi: 10.1300/J125v14n01_08

Whitlock, J., \& Hamilton, S. (2001). Youth development principles and practices: Defining what it is and is not. NY: Unpublished manuscript, Department of Human Development, Cornell University. 